\title{
ŽIVOT FRANTIŠKA ŽÁKA SJ (1862-1934) A JEHO TROJIČNÍ TEOLOGIE
}

C T I R A D VÁCLAV P O S PÍŠ I L

$\mathrm{T}$ en, kdo zkoumá dějiny české trinitární teologie a christologie nevyhnutelně narazí na objemná díla, jejichž autorem je František Žák SJ, anebo česky T.J., jak se coby vlastenec podepisoval on sám. Jelikož životu a dílu této nesporně zajímavé osobnosti prozatím nebyla věnována taková pozornost, jakou by si zasloužila, ${ }^{1}$ pokusíme se v následujícím příspěvku zmíněnou mezeru poněkud zacelit. Pohnutkou k tomuto počinu je i skutečnost, že $\mathbf{v}$ příštím roce si připomeneme sto padesáté výročí narození tohoto velmi plodného autora.

Vzhledem k tomu, že česká odborná literatura prozatím nedisponuje podrobnějším editovaným životopisem Františka Žáka, první bod této studie, věnovaný právě zmíněné tematice, nebude pouze širším kontextem naší následné analýzy, ale také přínosem k dějinám české teologie. V následujících bodech pak podrobíme kritické analýze ta díla našeho autora, která se přímo týkají předmětu našeho zájmu.

Základním zorným úhlem, z něhož budu přistupovat k vyhodnocení přínosů F. Žáka v oblasti trinitární teologie bude to, k čemu jsem dospěl ve své monografii věnované tajemství Nejsvětější Trojice. ${ }^{2}$ Je pochopitelné, že jiní autoři budou moci při svých interpretacích zvolit jiná hlediska, čemuž pak pochopitelně budou odpovídat jejich hodnocení, která se budou poněkud lišit od těch, k nimž jsem dospěl já. Každopádně si ale musíme vždy položit otázku, zda analyzovaná

1 Srov. FARRUGIA, Edward G. Encyklopedický slovnik krestanského Východu, Olomouc: Refugium: 2008 - český překlad je obohacen o celou řadu hesel. Bohužel heslo „František Žák“ bychom zde hledali marně. Jak uvidíme níže, určitě by si připomínku $\mathrm{v}$ takto tematicky zaměřené encyklopedii zasloužil.

2 Srov. POSPÍŠIL, Ctirad Václav. Jako v nebi, tak i na zemi. Náćrt trinitární teologie, 2. vydání, Kostelní Vydří: Karmelitánské nakladatelství - Praha: Krystal, 2010. 
trinitologie je esenciálně kompletní. Dále je dnes povinností věnovat pozornost především klíčovému problému trinitologie, totiž tomu, jak náš autor pojímá poměr mezi ekonomickou a imanentní Trojicí, protože na tom pak zcela jednoznačně závisí promítání tohoto stěžejního mystéria naší víry do ostatních částí systematické teologie a především do života. Konečně je třeba předeslat, že v citacích ze Žákových spisů a př́ípadně z dalších děl starších českých teologů převážně zachováváme původní ortografii, která se může $\mathbf{v}$ některých ohledech lišit od dnešních norem a od toho, jaký pravopis je uplatňován v této studii.

\section{Dílo a život F. Žáka}

Když se zahledíme do katalogů našich knihoven a zadáme jméno našeho autora, okamžitě zjistíme, že od něj pocházejí úctyhodně objemné svazky s titulem Soustavná katolická vérouka pro lid. Díl první, I. O pravé viŕe. II. O církvi. III. O podání a Písmè. IV. O Bohu jediném $v$ Trojici, Praha: Nakl. V. Kotrba, Dědictví Svatojanské, 1915, 566 stran; Soustavná katolická vérouka pro lid. Díl druhý. Č́st první. V. O Bohu tvůrci. VI. O Bohu vykupiteli (část prvni: O osobě Pána Ježíse Krista), Praha: Nakl. V. Kotrba: Dědictví Svatojanské, 1917, 360 stran; Soustavná katolická vérouka pro lid. Díl druhý. Část druhá. O Bohu vykupiteli, o P. Marii a svatých, o milosti, o Zákonè Starém a Novém, Praha: Nakl. V. Kotrba, Dědictví Svatojanské, 1920, s. 361-780; Soustavná katolická vérouka pro lid. Díl tretí. O svátostech, Praha: Nakl. V. Kotrba, Dědictví Svatojanské, 1925, 672 stran; Soustavná katolická vérouka pro lid. Díl čtvrtý. Ćást prvá. IX., O Bohu dokonavateli, Praha: Nakl. V. Kotrba, Dědictví Svatojanské, 1928, 322 stran. Ačkoliv by se dalo čekat, že podle titulu čtvrtého svazku by měl následovat ještě svazek IV.2, je patrné, že náš autor skutečně sepsal kompletní dogmatickou teologii, jíž předřadil témata, která se dnes řadí do teologie fundamentální. Jeho snažení mělo stejný záměr jako Populárni dogmatika J. V. Jirsíka na počátku čtyřicátých let devatenáctého století, jejíž rozsah ovšem F. Žák několikanásobně překročil. Trinitární teologie se výrazně týká také objemná sbírka tematických kázání: O Bohu a jeho vlastnostech, Praha: Nakl. V. Kotrba, 1908-1909, 828 stran.

Dále je třeba zmínit tř́śsvazkové dílo věnované christologii a soteriologii: Pán Ježíš Kritus: jeho osoba, 1. díl, Opava: Slezská lidová tiskárna, 1930, 315 stran; Pán Ježís Kristus: jeho dílo, 2. dil, Opava: Slezská lidová tiskárna, 1930, 223; Pán Ježiš Kristus: Jeho život, 3. díl, Opava: Slezská lidová tiskárna, 1930, 588 stran. Jedná se zřejmě o nejobjemnější 
monografické zpracování daného tématu od českého autora a v češtině v celém 19. a 20. století, což samo o sobě volá po kritické analýze. K podobnému závěru vybízí také další objemné teologické dílo: Eucharistie, Opava: Slezská lidová tiskárna, 1933, 460 stran. Za zmínku stojí také sbírka kázání: Vývoj mariologického dogmatu do roku 400, Hradec Králové: Tiskové družstvo, 1924. ${ }^{3}$

Náš autor vydal ještě dlouhou řádku promluv, krátkých pojednání pochopitelně náboženských, ale také vlasteneckých, ${ }^{4}$ pocházejí od něho divadelní hry, ${ }^{5}$ romány, ${ }^{6}$ skládal texty písní, básně, ${ }^{7}$ sepsal dokonce dějiny české literatury, ${ }^{8}$ zabýval se sociální a politickou problematikou. ${ }^{9}$ Vzhledem k blížícím se oslavám Cyrila a Metoděje by mohla být zajímavá také sbírka Žákových kázání na toto téma. ${ }^{10}$

V Časopisu katolického duchovenstva nacházíme celou řadu příspěvků z pera našeho autora, povětšinou věnovaných problematice Ruska a pravoslaví. Trinitární teologie a pneumatologie se týká především receneze: ŽÁK, František. Ischožděnie sv. Ducha. Veselenskoje pervosvjaščenstvo. Izdanie egeja Staškova, Frýburk v Breisigavě 1886, ČKD 1894, č. 7, s. 431-435. Zajímavá by mohla být také stat' uveřejněná na pokračování, která se týká problematiky poměru Rusů k Florentskému koncilu: srov. ŽÁK, František. Rusové na koncilu florentském. Dle P. Pavla Frielinga T.J. podává F. Žák, ČKD 1903, č. 1, s. 17-20; 1903, č. 2 , s. 85-88; 1903, č. 3, s. 172-179; 1902, č. 5, s. 325-333; 1903, č. 6-7,

3 Na pomezí mezi mariánskou a mariologickou literaturou se nachází dílo: ŽÁK, František. Promluvy. Cyklus III. Ave Maria. Promluvy o Panně Marii, Praha: Nakl. V. Kotrba, 1914, 144, stran.

4 Srov. např. ŽÁK, František. Odněmčeme se!, Praha: Nakl. V. Kotrba, 1921, 30 stran (pod pseudonymem: V. Hradský).

5 Ačkoliv jsme neměli možnost následující text konzultovat, jeho titul dává tušit, že F. Žák by mohl patřit také mezi první české autory sci-fi literatury: František Žák, Pozdrav z Marta: Veselohra o dvou jednánich, Hradec Králové: Tiskové družstvo, 1925, 48 stran (pod pseudonymem: V. Hradský).

6 Srov. např. ŽÁK, František. Okliky: román ze společenského života, Praha: Nakl. V. Kotrba, 1933, 236 stran (pod pseudonymem: V. Hradský).

7 Srov. např. ŽÁK, František. Lucerny: verše a prosa. Díl první, Praha: V. Kotrba, 1919, 195 stran.

8 Srov. ŽÁK, František. Stručné dějiny českého písemnictví. Díl prvni. Doba stará a stredni (od počátků pisemnictvi do sklonku 18. století), Telč: E. Šolc - Praha: J. Bačkovský, 1906, 121 stran, (pod pseudonymem V. Hradský); ŽÁK, František. Stručné déjiny českého písemnictví. Díl druhý. Devatenácté století, Telč: E. Šolc, 1906, 259 stran.

9 Srov. např. ŽÁK, František. Krestanský socialismus ve skutečnosti. Vzpominky z cest po Francii. Našim dẻlníkům vénuje František Žák, Praha: V. Kotrba, 1893, 16 stran; ŽÁK, František. Promluvy. Cyklus VII. Církev a stát, Praha: Nakl. V. Kotrba, 1921, 66 stran.

10 Srov. ŽÁK, František. Sv. Cyril a Metodèj: Devét promluv; Sv. Vojtěch: Osm promluv, Hradec Králové: Tiskové družstvo, 1931, 143 stran. 
s. 407-418; 1903, č. 9, s. 563-572. Uvedené statě nebudeme analyzovat, protože z nich náš autor čerpal při sepisování své Soustavné katolické vérouky pro lid. Problematiky Filioque a dějin ruskéteologie se týká článek: ŽÁK, František. Ruské spisy polemické v době domogolské. ČKD 1909, č. 7-8, s. 536-539. Problematiky vztahu k pravoslaví se pochopitelně týká i článek: ŽÁK, František. K otázce unionismu. ČKD 1929, č. 4, s. 321-332. Nezajímavý není ani příspěvek: ŽÁK, František. Vzpomínky na ruskou pravoslavnou církev. ĆKD 1930, č. 5-6, s. 337-342; 1930, č. 7, 526-533. K téže tematice patří také stati: ŽÁK, František. Církev a stát na Rusi. ČKD 1931, č. 1-2, s. 100-111; O hříchu podle pravoslavných ruských teologů, $C K D 1931$, č. 7, s. 607-619. Zmínit by se dále ještě latinsky psaná recenze: ŽÁK, František. Po voprosam duchovnoj školy i ob učebnom komitétě při svjatom synodě. ČKD 1908, č. 1, s. 15-19.

Jak vidno, letmá procházka nesmírně bohatou bibliografií našeho autora prozrazuje jeho nebývalý tematický záběr a nezdolnou pracovitost, pročež určitě není pochyb, že jeho životu a dílu stojí za to věnovat pozornost i dnes. Náš výčet ale musíme doplnit o jeden velmi důležitý údaj. František Žák je totiž autorem celé řady textů duchovních písní, z nichž především dvě se zpívají velmi často i dnes, totiž „Ježíši Králi““ (1912) a „Budiž věčně velebena“ (1908). ${ }^{11}$

Ačkoli primárním předmětem našeho zájmu jsou zejména myšlenkové struktury vybraných děl, pak v případě F. Žáka, jak již bylo naznačeno, padá důraz také na jeho životopis. Podařilo se nám totiž nalézt zatím nepublikovaný samizdatový zdroj, ${ }^{12}$ který obsahuje řadu velmi zajímavých informací, jež nám potopitelně napomohou k lepšímu porozumění myšlenkovému odkazu této pozoruhodné a nesmírně plodné osobnosti. ${ }^{13}$

11 Srov. Kancionál, Praha: Zvon, 1995, č. 707; 801. F. Žák pochopitelně složil slova mnoha jiných písní, dokonce také „Českou mši zádušni“ a „Českou mši.“ Zajímavá je rovněž prosebná píseň za sjednocení Slovanů, z níž si dovolím připomenout následující slova: 1. sloka: „Svatý Cyril s Metodějem káží slávských po vlastech, / obraz dojímavě sladký, / svaté Dítko v rukou Matky, / otvírá jim srdce všech. / Matičko, nám prosby vroucí za Slovany nitrem zní, / spoj nás vírou, spoj nás láskou / pod tvou bílou korouhví.“ Srov. PITRUN, Bernad. P. Žák, s. 217 (strojopis uchovávaný v knihovně u Sv. Ignáce v Praze, srov. s. 213-220).

12 Srov. PITRUN, Bernard. P. Žák František de Paula T.J., 264 stran strojopisu A4, 1978 uloženo v knihovně SJ v Praze u Sv. Ignáce. Autor v tomto spisu velmi zaníceně a také zasvěcení informuje o životních osudech a díle F. Žáka, předkládá řadu citací z jeho článků a osobních zápisků. Literární druh spisu kolísá mezi faktografickou monografií a beletristickým zpo̊sobem líčení některých epizod.

13 Stručnou vzpomínku na Fr. Žáka lze najít na adrese: www. jesuit.cz/vzpomínky. Jedná se ovšem o pouze obecnou a značně neúplnou jednostránkovou informaci, jejímž zdrojem je evidentně výše uvedený strojopis B. Pitruna. 
Otec našeho autora, František Žák starší, se narodil 27. 8. 1825 v Brně, matka se za svobodna jmenovala Tereza Voborníková. František Žák starší pracoval jako lesník ve východních Čechách, kde se v myslivně „Hvězda“ u Police nad Metují dne 15. 5. 1862 narodil František (z Pauly) Žák jako druhorozený. Základní školu vychodil v nedalekém Žd'áře. V roce 1883 absolvoval gymnázium v Broumově, které řídili benediktini. Vyučovalo se zde pochopitelně německy. ${ }^{14}$ Téhož roku začal na pražské teologické fakultě frekventovat teologickou fakultu. ${ }^{15}$

Kněžské svěcení přijal 5. 6. 1887 v Praze a primici slavil den poté u Sv. Salvatora. Rok působil jako kaplan ve farnosti Michle, od roku 1888 pak jako kaplan u Sv. Ludmily na Vinohradech. ${ }^{16}$ Byl mnohostranně činný jako autor pojednání a článků, působil v řadě spolků, hodně cestoval. ${ }^{17} \mathrm{~V}$ roce 1894 se mu podařilo obdržet po řadě peripetií vízum k cestě do Ruska, kde navštívil jako jeden z prvních českých kněží Petrohrad, Moskvu, Kyjev a celou řadu monastýrů. K žádosti musel doložit potvrzení, že není členem Tovaryšstva Ježíšova, protože příslušníci zmíněné řeholní rodiny byli v carském Rusku 19. století vysoce nevítanými osobami. Na své cestě byl vlídně přijat pravoslavnými duchovními a v různých klášterech, seznámil se s životem ruské církve a především $\mathrm{s}$ bohatou ruskou teologickou literaturou, což se pochopitelně později promítlo jako originální přínos nejenom do jeho Soustavné katolické vérouky pro lid, ale také do řady článků např́íklad v ČKD, jak jsme měli možnost konstatovat. Navázané kontakty pochopitelně ve zbytku svého plodného života využíval v unionistickém hnutí. Jeho postoj k pravoslaví dokumentují následující slova z jednoho jeho článku:

Ruský lid milujeme, ruskou církev v mnohé příčině ctíme. Seznáváme zde mnohé, co je dobré, krásné a povzbuzující. Věcné a spravedlivé kritice se vyhýbat nemíníme, avšak zákon pravdy a lásky rovněž nepřekročíme. ${ }^{18}$

František Žák věnoval nemálo sil také sociálnímu učení a praxi církve, byl horlivý vlastenec, autor mnoha článků, básní, divadelních

14 Srov. PITRUN, Bernad. P. Žák, s. 17-21. Dlužno poznamenat, že česká výuka na středních školách byla v našich zemích možná až po roce 1864. Srov. HAVRÁNEK, Jan, Budování české univerzity a její působení jako centra české vzdělanosti (1882-1918). KAVKA, František - PETRÁN, Josef - HAVRÁNEK, Jan (ed.), Déjiny Karlovy univerzity III, 1802-1918, Praha: Karolinum, 1997, s. 183-206.

15 Srov. PITRUN, Bernad. P. Žák, s. 24.

16 Srov. tamtéž, s. 26.

17 „V letech 1889-1892 navštívil postupně Belgii, Dánsko, Francii, Německo, Polsko, Uhry.“ Tamtéž, s. 29.

18 ŽÁK, František. Fejeton z cesty po Rusku. Vlast 1894, č. XI., s. 646. 
her, dokonce i kuchařských receptů. Určitě nebude bez zajímavosti připomenout celou plejádu pseudonymů, pod nimiž také publikoval: V. Hradský, Vlastimil, Vlastislav, Pravdomil, Discipulus, Starý vlastenec, Alois Klášterský, František Saleský, A. Simerská, Adéla Jindřišská, řada zkratek a značek. ${ }^{19} \mathrm{Na}$ poli apologetiky pracoval v časopise Obrana, který vznikl v roce 1884. Od roku 1894 ho redigoval sám František Žák. V této době jej také navštívil slovenský vlastenecký kněz Andrej Hlinka, s nímž pak po dlouhá léta spolupracoval. ${ }^{20}$

V roce 1898 náš autor vstoupil do Tovaryšstva Ježíšova. Noviciát absolvoval v Trnavě. ${ }^{21}$ Hluboce na něj zapůsobil útisk slovenského národa. Vztah ke Slovensku se stal také jedním z podstatných rysů jeho dalšího působení. Uvědomíme-li si situaci vztahů mezi Čechy a Slováky v oné době, pak danou záležitost musíme hodnotit jako velmi významnou. Zkrátka a dobře F. Žák patřil k osobnostem, které výrazně přispěli k prohlubování vztahů mezi Čechy a Slováky a na rozdíl od téměř naprosté většiny českých slovakofilů opravdu Slovensko a jeho problémy znal. K srdci slovenského člověka měl navíc jedinečnou př́istupovou cestu ve svém kněžství. ${ }^{22}$ Od roku 1900 studoval filosofii v Bratislavě - tehdejším Prešpurku. ${ }^{23}$ Od podzimu 1901 do podzimu 1903 naslouchal přednáškám v oboru teologie v Innsbrucku. ${ }^{24}$ Následoval návrat do Trnavy. Pak ve školním roce 1904/05 absolvoval tak

19 Srov. PITRUN, Bernard. P. Žák, s. 195-196.

20 Srov. zejména PITRUN, Bernard. $P$. Žák, s. 92nn.

21 Srov. tamtéž, s. 58nn.

22 Je faktem, že: „Vzájemné vztahy [mezi Čechy a Slováky] byly prakticky až do roku 1914 postaveny vždy na několika málo konkrétních osobnostech či mimořádných událostech dějin, které nezakládaly další kontinuitu. STEHLÍK, Michal.Češi a Slováci 1882-1914. Nezřetelnost společné cesty, Praha: Togga, 2009, s. 15. Zlomovými byly především roky 1848 a 1882 . Každopádně ale platí, že bližší vztahy se rodily zejména v letech 1907-1914 - „za pouhých sedm let tohoto období se stalo na poli česko-slovenských vztahů více závažných událostí nežli za celé půlstoletí předtím“ (s. 154). Na podzim roku 1907 Andrej Hlinka absolvoval velké přednáškové turné po Čechách a Moravě. „Do popředí se dostává konečně organizace zajištující spolupráci - Československá jednota“ (s. 154). Jestliže M. Stehlík konstatuje: „... ve všech těchto oblastech se vzájemné vztahy různě rozvíjely, přičemž hlavní tíha vždy jednoznačně ležela na jednotlivcích. Mám za to, že v této oblasti lze i přes dosavadní znalost mnoha jednotlivých událostí a procesů stále nacházet nové informace a pohledy“ (s. 155), pak není nesnadné uhodnout, že i naše zjištění týkající se života, díla a osobních kontaktů F. Žáka vyznívá právě jako takovýto přínos k otázce česko-slovenských vztahů v klíčově době jejich uzrávání. Role F. Žáka se ukazuje být velmi významná i proto, že české prostředí vykazovalo velkou neznalost slovenského prostředí a situace (srov. s. 156), kterýžto limit F. Žák jednoznačně překračoval. Srov. PITRUN, Bernard. P. Žák, s. 81nn.

24 Srov. tamtéž, s. 87. 
zvanou třetí probaci ve Freienbergu u Lince. Dne 16. července 1905 se František Žák vrátil do Prahy k Sv. Ignáci, kde, po krátkých působeních mimo Prahu, žil a pracoval od 4. 9. 1907. V roce 1908 spolu s dalšími bratry z Tovaryšstva Ježíšova založil časopis mariánských družin Ve službách Královny, ${ }^{25}$ který je určitě důležitý z hlediska dějin české mariologie. V letech 1908-1909 vycházela v nakladatelství V. Kotrby také důležitá a obsáhlá série teologických kázání $O$ Bohu a jeho vlastnostech, o níž jsme se již zmínili v přehledu hlavních spisů F. Žáka v úvodu tohoto oddílu.

Dne 7. března 1909 přednášel František Žák akademikům v Arnoštově koleji o tajemství Ježíše Krista, pak vedl s účastníky dialog, při němž se podle všeho zrodil jeho záměr napsat česky vědecký život Ježíše Krista. ${ }^{26}$ Zmíněnému a výše citovanému dílu se pak věnoval řadu let. Za tímto účelem vícekrát trávil celé měsíce $\mathrm{v}$ knihovně a při rozhovorech s odborníky z oblasti teologie a filosofie v tyrolském univerzitním městě Innsbrucku. První takový pobyt se odehrál od ř́jna 1912 do 11. července 1913. ${ }^{27}$ Druhý pobyt v Innsbrucku náš autor podnikl v letních měsících roku 1914 (5. 7. -5. 8.).

V této době oslovil Františka Žáka biskup Antonín Podlaha a požádal ho, aby napsal českou věrouku - dogmatiku, která pak vznikala po celých deset let. Vyšla v nakladatelství V. Kotrby (1915-1928). Studijní pobyty $\mathrm{v}$ zahraničí tedy nebyly zaměřeny jen na př́pravu christologie, jak neustále zdůrazňuje otec Pitrun, ale byly spjaty také s přípravnými pracemi na Soustavné katolické vérouce pro lid. Každopádně ale platí, že tato dogmatika úzce souvisí s prohlubováním christologie.

V době první světové války František Žák pokračoval ve své duchovní a publikační činnosti. Jeho bratr Karel narukoval a v Haliči upadl do ruského zajetí, z něhož se jako legionář vrátil přes Dálný východ a po moři do vlasti až v roce 1920.28 O postojích Františka Žáka svědčí následující výpověd:

Dojímalo ho hluboce, když viděl tělesnou bídu a duševní rozvrat českých lidí. $V$ důsledku toho tím více přilnul k těmto neubožejším a snažil se, seč mohl, i hmotně mírnit jejich bídu. $V$ roce 1915 téměř denně chodil

25 Srov. tamtéž, s. 133nn.

26 Srov. tamtéž, s. 139.

27 Srov. tamtéž, s. 148.

28 Srov. tamtéž, s. 151. 
do vojenského špitálu na Karlově sloužit mši svatou, přestože o nedělích musel u Sv. Ignáce binovat. 29

Navzdory neúnavné pastorační, publikační a charitativní činnosti nezapomínal na vědeckou práci, a tak v roce 1917 (9. 7.-11. 8.) opět zamířil do Innsbrucku, aby pokračoval ve sbírání podnětů ke svému zamýšlenému dílu o postavě Ježíše Krista. Mnoho katolických kněží výrazně přispívalo k boji za samostatnost nového českého státu. Například o svatodušních svátcích čeští spisovatelé podepsali petici za českou samostatnost a první mezi podepsanými byl kněz Jindřich Šimon Bár. O rok později se dne 17. května konaly slavnosti u př́ležitosti 50. výročí položení základního kamene Národního divadla, jichž se F. Žák aktivně zúčastnil. ${ }^{30}$ Mezi strázně oné doby patřila také strašlivá epidemie španělské chřipky, která v Praze zahubila mnoho lidí zejména v říjnu 1918. Zemřeli i dva otcové jezuité. F. Žák rovněž onemocněl, chorobu však zdárně překonal.

Na začátku mladého Československa F. Žák s účastí prožíval napětí na Slovensku, kde nově příchozí čeští úředníci a intelektuálové mnohdy šírili antikřestanské a liberální postoje. ${ }^{31}$

V roce 1920 byl F. Žák představenými přeložen do Hradce Králové, kde působil dalších pět let. V roce 1924 se z podnětu Františka Žáka konaly po celé české zemi v den svátku sv. Václava ${ }^{32}$ manifestace věřících proti snahám zrušit 28. 9. jako památný národní den, což bylo

29 Tamtéž, s. 152.

30 Srov. Tamtéž, s. 162.

31 „Jako kdysi Mad’aři nám brali řeč, tak nyní zase Češi nám chtějí vzít pravou víru, bez níž Slováci nemohou žít. Nuž to nemůžeme dopustit.“ Z proslovu A. Hlinky 1918 v Praze. Tamtéž, s. 168.

Po Hlinkově uvěznění Žák reagoval následujícím způsobem: „Když našeho člověka (Čecha) někdo urazí, tož jsou z toho soudy a diplomatické nóty. Sám však uráží, aniž si dá otázku, má-li právo vláčeti v bahně čest svého bližního a ostouzeti ho. ... My katoličtí Češi přejeme dr. Hlinkovi, aby se dařilo jeho další činnosti ve prospěch drahého mu slovenského lidu, nebot vítězství myšlenky, za niž bojuje, bude nejlepším smazáním všech křivd, jež musí vystáti od svých nepřátel.“ Na adresu radikála slovenského patera Jehličky však reagoval ostře kriticky: „Dr. Jehlička neměl odvahy Hlinkovy a sám Hlinka se v něm zmýlil, přecenil ho. Změnil se, jak známo, v zuřivého odpůrce Čechů, proti nimž štval a psal nenávistné pamflety, letáky, které byly hrozné, neuvěřitelné. Mně nešlo do hlavy jedno: Jak může profesor katolické morálky srovnat své jednání se svědomím a jak se může vůbec modlit k Bohu. Inu uražená pýcha! Pýcha je vášeň vpravdě d'ábelská،“ ŽÁK, František. Život, II, květen 1920.

32 Svatováclavské tematice se F. Žák věnoval již před rokem 1918. Srov. ŽÁK, František. Svatý Václav: Dvanáct réč́l, Praha: Nakl. V. Kotrba, 1906, 126 stran; ŽÁK, František. Svatá Ludmila, veršem sepsal František Žák, Praha: Nakl. V. Kotrba, 1907, 47 stran; ŽÁK František. Svatý Václav - veršem sepsal František Žák, Praha: Nakl. V. Kotrba, 
korunováno úspěchem, a tak byl v roce 1925 poprvé v nové republice slaven jako státní svátek. ${ }^{33}$

V roce 1925 František Žák absolvoval studijní pobyt v Belgii a v Innsbrucku, kde opět pokračoval v př́pravách na sepsání svého díla o Ježíši Kristus. Pak se odebral do svého nového působiště ve Slezsku, přesněji řečeno v Opavě. Zde pracoval až do srpna 1931, kdy byl povolán zpět do Prahy ke Sv. Ignáci. ${ }^{34}$ V letech 1930 také vyšly v Opavě tř̌i svazky jeho díla o osobě, díle a životním příběhu Ježíše Krista, které jsem uvedli výše v přehledu hlavních spisů našeho autora.

V roce 1932 oslavil v Praze sedmdesátiny. Na akce s tím spjaté bylo utraceno 3500 tehdejších českých korun, což byla valná část honoráře za jeho román Svétoběžník (1933)..$^{35}$

V posledních měsících roku 1934 František Žák vážně churavěl. Podle svědectví měl pronést následující zajímavá slova:

Ano, psal bych romány. Hled', kdo pak čte moje náboženské spisy? Snad někteří kněží, ale jen málokdo. Chtějí pořád nové a spíše zahraniční, kdežto laici musí mít jinak psané knihy, zajímavé. Tato doba vůbec chce něco jiného, lehčího, zábavného, poutavého. Proto bych psal romány a v nich rozvedl náboženské pravdy, a dal je prodávat za levný obnos, aby se dostaly všude a k mladým lidem. To pomůže víc, než kázat v kostele. ${ }^{36}$

V těch slovech je nemálo hořkosti a zračí se v nich úděl českého teologa. Stejně jako tenkrát i dnes platí, že toho českého si vážíme méně než překladové literatury. Jeho srdce dotlouklo 22. prosince 1934 v osm hodin ráno $\mathrm{v}$ sobotu před čtvrtou nedělí adventní v nemocnici Na Františku. Pohřeb se odehrál 26. prosince odpoledne u Sv. Ignáce. Jeho tělo je uloženo na Vyšehradě v hrobě otců jezuitů.

V následujících bodech podrobíme analýze příslušné pasáže ze dvou výše avizovaných spisů Františka Žáka. Z chronologického hlediska budeme věnovat pozornost nejprve trinitární tematice obsažené ve sbírce kázání $O$ Bohu a jeho vlastnostech, následně přistoupíme ke kritické četbě části věnované tajemství Trojice ze Soustavné katolické vérouky pro lid.

1908, 67 stran; ŽÁK, František. Svatý Václav: program českého národa, Praha: Nakl. V. Kotrba, 1910, 16 stran.

33 Srov. PITRUN, Bernard. P. Žák, s. 180.

34 Srov. tamtéž, s. 190.

35 Srov. tamtéž, s. 192.

36 Srov. tamtéž, s. 242. 


\section{Analýza trinitologie v díle: František Žák T.J., O Bohu a jeho vlastnostech, kázání, Praha: Nakl. V. Kotrba, 1908, 828 stran}

Ještě než přistoupíme k vlastní analýze pasáží věnovaných trinitologii, je třeba si uvědomit žánr této publikace: Jedná se o katechetická kázání, tedy o jakousi katechezi pro dospělé. Podle obsahu spisu lze usuzovat na to, že adresátem byla především katolická inteligence. Autor bohužel tuto sbírku celkem 85 promluv neopatřil žádným úvodem, kde by vyjasnil své záměry a hlavní inspirační zdroje. Neříká také nic o celkové struktuře díla.

Vzhledem k tomu, že namnoze se kázání dodnes bohužel velmi často zvrhává v moralizování, je třeba hodnotit velmi pozitivně, že František Žák se v této sérii promluv snažil mluvit především o Bohu a jeho tajemstvích.

Nejprve představíme celkovou strukturu díla a ozřejmíme místo, které $\mathrm{v}$ něm přísluší trinitární teologii. Následně se zaměříme na podrobnější analýzu př́islušné části věnované tématu, o nějž se v souvislosti s tématem naší monografie zajímáme.

\subsection{Celková struktura díla}

Ačkoliv autor sám dílo rozděluje jenom na 85 promluv, není nesnadné v něm objevit samostatné větší celky. Prvních 21 kázání37 je věnováno problematice poznání Boha ze strany člověka, důkazům Boží existence a popření ateismu. Dalo by se tedy říci, že v této části převládají témata fundamentálně teologická a otázky teologické gnoseologie. Jedenadvacátá promluva ${ }^{38}$ představuje Boha jako absolutní pravdu, dobro, krásu a život. Není zde ovšem ani sebemenší náznak trinitárních souvislostí.

Promluvy 22-2739 pojednávají přímo o Nejsvětější Trojici, přičemž poslední dvě kázání můžeme hodnotit jako náznak pneumatologie. Každopádně není bez zajímavosti, že tajemství Trojice je předřazeno rozboru vlastností Boží esence. Již na tomto místě je ale třeba podotknout, že trinitární mystérium je od zbytku díla v určitém ohledu izolováno, protože o vlastnostech Božích se pochopitelně pojednává na základě schématu ,jediný Bůh - svět“. Tuto nesourodost však

37 Srov. ŽÁK, František. O Bohu a jeho vlastnostech, kázání, Praha: Nakl. V. Kotrba, 1908, zde s. $7-195$.

38 Srov. tamtéž, s. 195-203.

39 Srov. tamtéž, s. 204-261. 
nemůžeme klást Žákovi osobně za vinu, nebot' to přesně odpovídá dobovému stavu teologické reflexe.

Následuje řeč číslo 28 věnovaná rozboru víry a promluva 29 o mučednících jako o svědcích víry. ${ }^{40}$ Kázání 30-33 hovoří o Boží všemohoucnosti a o jeho díle stvoření. ${ }^{41}$

Posléze jsou nám předkládány jednotlivé vlastnosti Boží (kázání č. 34-43), ${ }^{42}$ což by byla pasáž spadající do dogmatického pojednání O jediném Bohu. Kázání 44-4843 jsou věnována Boží prozřetelnosti a představují návrat k pojednání o stvoření, jednalo by se o otázku řízení světa ze strany Boha.

Kapitoly 49-5844 mají za téma Boží milosrdenství, do něhož je vkomponováno tajemství vtělení a soterilogie. V kázání č. 50 se F. Žák zabývá pohnutkami vtělení a podle všeho se výrazně přiklání k podmíněnosti inkarnace Slova hř́chem. ${ }^{45} \mathrm{~S}$ právě zmíněnou tematikou souvisí také kázání 59 o Boží trpělivosti. ${ }^{46}$

Velký počet promluv o Boží spravedlnosti (kázání č. $60-79)^{47}$ otvírá prostor, v němž kazatel může rozvinout morálně teologické otázky a věnovat několik úvah také eschatologii. Eschatologickými tématy se pak F. Žák zabývá i v poslední sérii promluv (č. 80-85). ${ }^{48}$

Máme-li danou strukturu vyhodnotit, vysvítá, že úmyslem F. Žáka bylo vyložit podstatné části katolické dogmatiky a v určitých př́padech také morální teologie na základě základního východiska, jímž je obraz Boha křestanské víry. Schází ovšem sakramentologie a eklesiologie, antropologie je přítomna roztroušeně po celém díle, totéž platí o nauce týkající se milosti. Řečenému by odpovídalo pojetí teologie jako vědy primárně o Bohu. Pastorační zaměření zase ukazuje na to, že teologie je zde chápána jako praktická nauka. Celkový záměr vykazuje prvky geniality, protože s ničím podobným sepodle mých znalostí v české teologické literatuře nesetkáme. Dlužno podotknout, že velmi podobná výchozí idea vévodí jednomu z nejvěhlasnějších spisů Bonaventury

$\begin{array}{ll}40 & \text { Srov. tamtéž, s. } 270-279 . \\ 41 & \text { Srov. tamtéž, s. 280-315. } \\ 42 & \text { Srov. tamtéž, s. 316-416. } \\ 43 & \text { Srov. tamtéž, s. 417-466. } \\ 44 & \text { Srov. tamtéž, s. 467-563. } \\ 45 & \text { Srov. tamtéž, s. 477-485. } \\ 46 & \text { Srov. tamtéž, s. 564-573. } \\ 47 & \text { Srov. tamtéž, s. 574-762. } \\ 48 & \text { Srov. tamtéž, s. 767-825. }\end{array}$ 
z Bagnoregia, Breviloquium z roku 1257.49 František Žák tohoto autora sice zmiňuje, ${ }^{50}$ nicméně po pročtení jeho díla není možno usuzovat na nějakou souvislost s jeho sbírkou kázání a uvedeným spisem Serafického učitele, v němž se také tematika vlastností Boha propojuje s mystériem Otce, Syna a Ducha svatého mnohem znatelněji, nežli v objemném svazku kázání z pera českého teologa a kazatele počátku dvacátého století.

\subsection{Rozbor pasáže vènované trinitologii}

Jak již bylo řečeno, trinitárního mystéria se týká celkem šesti promluv, což je méně než deset procent z celkového počtu osmdesát pět. Nezajímavé rozhodně není, že trinitární tematika je zařazena před vlastní pojednání o vlastnostech Boží esence, nicméně v celém komplexu promluv působí tato partie poněkud izolovaně, protože celý zbytek knihy je konstruován na základě schématu „jeden Bůh - svět“. Lze rovněž konstatovat, že posluchačům, případně čtenářům těchto promluv nemohlo být jasné, jaký je praktický význam trinitárního mystéria. To vše ale jenom dokumentuje stav trinitologie na počátku dvacátého století. Potvrzuje se, že manualistika nedokázala dostát principu anologie víry, nebot $\mathrm{v}$ jejím podání nedocházelo k hlubšímu propojování jednotlivých traktátů, což je zejména $\mathrm{v}$ případě trojičního mystéria velmi závažným problémem.

První kázání (22): František Žák navzdory řečenému zahajuje konstatováním, které se do jisté míry podobá tomu, co nacházíme v dnešním Katechismu Katolické církve, č. 234:

Učení o nejsv. Trojici je největším tajemstvím naší sv. víry. Jeden Bůh ve třech rozdílných osobách, tot́ věc, již rozluštiti lidský rozum marně se snaží. 51

Na rozdíl od KKC se zde ale nekonstatuje, že se jedná také o největší tajemství křestanského života.

49 Srov. POSPÍŠIL, Ctirad Václav. Bonaventura z Bagnoregia a základní přístupové cesty k jeho spisu Breviloquium. In BONAVENTURA, Breviloquium - Kompendium scholastické teologie, Vyšehrad: Praha 2004, s. 15-54.

50 „Pohlíźím-li na obrazy našich velkých světců, vidím mezi nimi sv. Augustina, Bonaventuru, Tomáše Aq. a jiné, kteřá byli veleduchové, jakých se za století narodí sotva jeden. Ž́́K, František. $O$ Bohu, s. 230.

51 Tamtéž, s. 204. 
Následuje shrnutí starozákonní přípravy zjevení Trojice, kde náš autor operuje především s místy, kde Bůh o sobě hovoří v plurálu (srov. Gn 1,$26 ; 3,22 ; 11,7)$, v čemž spolu s církevními otci spatřuje ozvěnu rozmluvy mezi osobami Trojice. Připomíná také Iz 6,3, kde se třikrát opakuje „svatý, svatý, svatý“, a Nm 6,24. Zmiňuje také starozákonní pasáže hovořící o moudrosti. ${ }^{52}$ Neumí však ještě rozlišit, že se jednalo o pouhé personifikace. Schází obvyklá odvolávka na scénu z Gn 18, tedy zjevení tří Božích poslů Abrahámovi. Žák také neřeší otázku, zda Jahve je Otec nebo celá Trojice. Prezentace novozákonních východisek trinitologie staví hlavně na Mt 28,19. ${ }^{53}$ Velmi zajímavé je následující tvrzení:

Že Bohu Otci se připisují božské vlastnosti, rozumí se samo sebou, nebot́ vše, co v Písmu se obecně o Bohu praví, praví se především o Bohu Otci. ${ }^{54}$

Toto tvrzení by mohlo naznačovat, že Jahve by měl být Bůh Otec. Jenomže Žák není ve své trinitologii důsledný, a tak tento základní princip dále nedomýšlí.

Božství Syna v Novém zákoně je dokumentováno odvolávkou na Jan 1,1. Zajímavá je ovšem argumentace ohledně božství Ducha svatého. Žák operuje místem Sk 5,3-4..$^{55}$ Ananiáš lhal nejprve Duchu svatému, následně se konstatuje, že lhal Bohu, z čehož se vyvozuje, že Duch svatý je Bůh. ${ }^{56}$ Je evidentní, že tento typ argumentace, zcela běžně se opakující v teologické a kazatelské literatuře 19. a počátku 20. století, má kořen v Katechismu Tridentského koncilu. ${ }^{57} \mathrm{~V}$ současnosti by ale

52 Srov. tamtéž, s. 206-207.

53 Srov. tamtéž, s. 207-208.

54 Tamtéž, s. 208.

55 „Ale Petr mu řekl: ,Ananiáši, proč satan ovládl tvé srdce, že jsi lhal Duchu svatému a dal stranou část peněz za to pole? Bylo tvé a mohl sis je přece ponechat; a když jsi je prodal, mohl jsi s penězi naložit podle svého. Jak ses mohl odhodlat k tomuto činu? Nelhal jsi lidem, ale Bohu!““

56 Srov. tamtéž, s. 209.

57 Srov. Katechismus $z$ nařizení snèmu Tridentského k pastýřum duchovním a z rozkazu Pia V. papeže řimského na svétlo vydaný, překlad Jan Herčík, Praha: Arcib. Knihtiskárna, 1867, s. 84. Na svou dobu vynikající jazyková úroveň překladu je zřejmě dlužna dohledu Václava Zikmunda.

Václav Zikmund, narodil se roku 1816 ve Štáhlavicích u Plzně a zemřel 5. října 1873, pochován je na Vyšehradě. Kněžské svěcení přijal v roce 1841. Do roku 1848 přednášel na německém gymnáziu v Písku. Byl také profesorem na Akademickém gymnáziu v Praze, arcibiskupským notářem, členem Královské české společnosti nauk, čestným členem Jednoty učitelské v Písku. Zabýval se českou a latinskou filologií, napsal první soustavné pojednání o české syntaxi. Konkrétní tituly: Gramatika jazyka českého 
tato argumentace obstála jen stěží, nebot' v pozadí daného novozákonního textu zřetelně stojí ještě ne zcela rozvinutá pneumatologie, konkrétněji řečeno pojímání „ducha“ svatého jako personifikované Boží moci. Pak je ovšem zřejmé, že lhaní tomuto „duchu“ je zároveň lhaním Bohu, aniž by se tím jasně proklamoval božský statut Ducha svatého jako osoby Trojice.

Prezentace bludů se omezuje na sabellianismus, jehož popis není právě výstižný. Podle Žáka by sabelliáni měli učit, že existuje jen jedna božská osoba, která má ale tři části. Stručné nastíněni podstaty arianismu obstojí. 58

Ve druhé promluvě (23) po prezentaci disputace sv. Konstantina s muslimy ohledně tajemství Trojice následuje výklad psychologické teorie. V dané souvislosti překvapí, že není zmíněn sv. Augustin. Druhá božská osoba vychází z Otce jako jeho sebepoznání v podobě Slova, ${ }^{59}$ zatímco Duch svatý vychází z vůle Otce i Syna jako Láska. ${ }^{60}$ František Žák svým postupem dokládá, že psychologická teorie byla na počátku 20. století primární př́stupovou cestou k výkladu tajemství Trojice. Teprve v druhé polovině dvacátého století narůstala kritika tohoto modelu, který je dnes stále více odsouván do pozadí jako ne př́liš vhodná ilustrace trojičního tajemství, protože celkem spontánně zaměňuje Otce, Syna a Ducha svatého z pouhé mohutnosti ve skutečnosti jedné „superosoby“ nebo jednoho Božího „supersubjektu“. Dlužno však podotknout, že Žák se snaží argumentovat Písmem, takže v jeho případě by nešlo o nadřazování přirozeného zjevení v podobě psychologické

pro nižši gymnasia. I. oddèleni, Zvykoslovi a tvarosloví, Praha: Nakl. I. L. Kober, 1865; Gramatika jazyka českého II oddèlení, Větosloví, vidy a rozmèry reči vázané, Praha: Nakl. I. L. Kober, 1866. Datace těchto prací bezesporu souvisí s tím, že od roku 1864 se mohlo v Čechách a na Moravě vyučovat na gymnáziích česky. Faktické informace pocházejí z: PETERA, Václav. Géniové církve a vlasti - přístupné na www.cdct.cz; dále z www.icpisek.cz. Dílo V. Zikmunda používal Jan Gebauer (†1907) - viz www .morfemy.cz. Srov. také: ZIKMUND, Václav. O písemnictví a dějinách mravouky bohovědecké. ČKD 1874, 4, s. 259-275; ĆKD 1874, 5, s. 345-373 - v poznámce se uvádí, že článek je součástí mravouky, na níž tento autor několik let pracoval, ale kvůli náhlému úmrtí v roce 1873 nedokončil.

Jan Herčík se narodil v roce 1835 v Lánech u Kolína, vysvěcen byl v roce 1860, zemřel 5. února 1869 tamtéž. Kromě Katechismu za nařizeni sněmu Tridentského přeložil do češtiny také Augustinova Vyznání. Informace pocházejí z: PETERA, Václav. Géniové církve a vlasti.

58 Srov. ŽÁK, František. O Bohu, s. 209.

59 Srov. tamtéž, s. 217.

60 „První vycházení dělo se poznáním. I lze předem uhádnouti, že druhé vycházení děje se vůlí. A tak tomu jest. Duch sv. nazývá se často láska; láska jest činností vůle." Tamtéž, s. 219. 
introspekce zjevení nadpřirozenému, jak je tomu u některých aplikací Augustinova myšlenkového odkazu běžné.

Následuje první delší zmínka o problematice Filioque. Náš autor ukazuje, že v Novém zákoně je Duch svatý nejen Duchem Otce, ale také Syna (srov. Gal. 4,6). ${ }^{61}$

Ve třetí promluvě (24) se setkáváme s velmi nedokonalou prezentací teorie vnitrobožských vztahů. Osoba odpovídá podle Žáka tomu, když řekneme ,já“. 62 Náš autor velmi správně kritizuje katechetická přirovnání, jejichž prostřednictvím se předkládá tajemství Trojice. Uvádí př́íklad ohně. Jeho hodnocení zní následovně:

Ale všechna tato přirovnání kulhají, nebot' světlo a teplo jsou jen vlastnostmi nebo následky ohně. ${ }^{63}$

František Žák hovoří o třech vztazích v Bohu, klasický model však uvádí vztahy čtyři, z nichž pouze tři jsou osobotvorné. Nikde se neříká, že osoba je substanciálním vnitrobožským vztahem. Relační teorie je ovšem zcela podř́zena oné psychologické:

Tak máme jednu přirozenost božskou, která má ony tř̀i skutečné vztahy v sobě, která existuje jako Otec, Syn a Duch svatý, která je sama od sebe jako Otec, poznaná čili zplozená jako Syn a milovaná jako Duch svatý. ${ }^{64}$

Vedle chyby v počtu vztahů je zde i omyl v připisování aseity jen Otci, protože aseita přísluší božství, a proto i Synovi a Duchu svatému stejně jako věčnost. $V$ pozadí se evidentně skrývá koncepce absolutní osoby Boha Otce, což pak nevyhnutelně vede k celé řadě nemalých problémů.

Následuje téma přivlastňování. ${ }^{65}$ Žák vůbec nehovoří o přivlastňování esenciálií a okamžitě mluví o přivlastňování stvoření Otci, vykoupení Synu a posvěcení Duchu svatému. Zdůrazňuje se, že díla navenek jsou všem osobám společná. Stojíme tak před modelem, na jehož základě se trinitologie prakticky omezuje pouze na oblast imanentní Trojice, zatímco celý zbytek teologie stojí na De Deo Uno.

V pasáži věnované poslání Syna a Ducha svatého nacházíme zajímavý pneumatologický titul:

61 Srov. tamtéž, s. 219.

62 Srov. tamtéž, s. 225.

63 Tamtéž, s. 226.

64 Tamtéž, s. 227.

65 Srov. tamtéž, s. 227-228. 
A potom chceme ještě něco připomenouti. Bůh božsky se miluje a jest $v$ této lásce věčně blažen. Tou láskou je Duch svatý, třetí božská osoba. Jest, abych tak řekl, živým božským dítkem lásky mezi Bohem Otcem a Synem. ${ }^{66}$

Další kázání (25) je plně zaměřeno na problematiku Filioque. František Žák zde prezentuje historii problému. Z celé kapitoly je zřejmé, jak byla právě tato otázka pro našeho představitele unionistických snah důležitá. Problém všem tkví v tom, že Žák vůbec neprezentuje východní verzi, podle níž Duch vychází z Otce skrze Syna. Není mu známo nic o podvojnosti západního a východního řešení. Nedokáže vysvětlit praktický význam tohoto sporu. Zajímavá je zmínka o ruském učenci, který přiznal, že spor o Filioque je ve skutečnosti jen záminka Východu, aby se nemusel sjednotit s Rímem. ${ }^{67}$ Poněkud drasticky působí hodnocení skutečnosti pádu Konstantinopole v roce 1453, k níž došlo o svatodušních svátcích, jako Boží trest za odmítání Filioque. ${ }^{68}$

Páté a šesté kázání (26 a 27) představují jakýsi nástin pneumatologie, v němž se autor věnuje především tomu, že Duch svatý působí osvícení, daruje milost, vlévá lásku. Velmi trefné je následující konstatování, které může být výzvou i dnes:

Křestané, jak málo zabýváme se u porovnání s působením Ducha svatého v nás, s ním a s Bohem vůbec! ${ }^{69}$

Ačkoliv to český teolog a kazatel nezmiňuje, v pozadí jeho provokativní výzvy můžeme tušit inspirace pocházející z encykliky Lva XIII., Divinum illud munus z roku $1897 .^{70}$

\section{Trinitologie v Soustavné katolické vèrouce pro lid}

Opět nejprve představíme dílo jako celek, v jehož rámci se nachází příslušná pasáž, kterou pak v druhém bodu budeme prezentovat a analyzovat.

66 Tamtéž, s. 229.

67 Srov. tamtéž, s. 239. Ač to Žák necituje, jedná se s velkou mírou pravděpodobnosti o publikace pod pseudonymem, uveřejněnou v: Revue internationale de théologie VI, 1898, s. 681-712.

68 Srov. ŽÁK, František. O Bohu, s. 240.

69 Srov. tamtéž, s. 246.

70 Srov. Lev XIII., Divinum illud munus, encyklika zde dne 9. 5. 1897; český překlad: Praha: Krystal, 1998, 37 stran; starší český překlad vyšel snad již v roce 1897, zřejmě v Brně, více informací se ale nepodařilo zjistit. Zmíněná encyklika měla ještě vyjít v: STŘíŽ, Antonín. Věnec Ducha svatého. Rozjímáni a modlitby svatodušni, Praha: Ladislav Mincíř, 1931, 71 stran (edice z roku 1948: 102 stran). 


\subsection{Výstavba díla}

Celková struktura Soustavné katolické vérouky pro lid vznikala více než třináct let. V roce 1915, tedy sedm let po výše analyzovaném díle, vyšel první díl, který obsahoval: Určitou fundamentální teologii I. O pravé víře (s. 9-135) (ve skutečnosti traktát o náboženství, zjevení a fundamentálně teologické pojednání o Ježíši Kristu, tedy demonstratio christiana) - II. O církvi (s. 136-303, demonstratio catholica) O podání a Písmě (304-401, o pramenech teologického poznání). Pak následuje kniha IV. O Bohu jednom v Trojici (s. 402-566).

V letech 1917-20 spatřil světlo světa druhý svazek obsahující pojednání: V. O Bohu stvořiteli (s. 1-152); VI. O Bohu Vykupiteli (s. 153-536, zahrnuje christologii, soteriologii, mariologii a dodatek o úctě svatých); VII. O milosti (s. 537-717); nečíslovaná př́loha: O Zákoně Starém a Novém (s. 718-770).

V roce 1925 si mohli zájemci zakoupit třetí díl, který byl jako kniha celý věnován pojednání číslo VIII O svátostech (666 stran).

O tři roky později, tedy v roce 1928, spatřil světlo světa čtvrtý díl, který byl věnován eschatologii (322 stran).

Již tato obecná prezentace odhaluje, že v tomto nejrozsáhlejším opusu našeho autora z dnešního hlediska nenalézáme pneumatologii ani dogmaticky pojatou eklesiologii, kteréžto traktáty se ovšem v prvních desetiletích dvacátého století zpravidla v kompendiích dogmatické teologie neobjevovaly.

Žákova dogmatika sice patří do manualistické epochy, nicméně není už strukturována do jednotlivých tezí a má ráz soustavného výkladu, jakéhosi naukového eseje rozčleněného do oddílů a pododdílů. Opět musíme konstatovat, že mystérium Nejsvětější Trojice se projevuje pouze $\mathrm{v}$ příslušném traktátu, mimo nějž se $\mathrm{s}$ ním ve zbytku této věrouky $\mathrm{v}$ podstatě nesetkáváme.

\subsection{Kritická analýza pasáže: O Bohu jediném v Trojici}

$\mathrm{V}$ úvodu autor tvrdí, že „rozpravy o Bohu jsou nejvznešenější část bohovědy“.71 Zároveň je zde zmíněno, že „Sv. František dal bratřím povolení studovati bohovědu. Jednou šel se podívat, kterak prospívají. Když slyšel, jak dokazují, že Bůh jest, pravil horlivě, že mají hledati důvody k vroucnější lásce Boží, a ne důvody pro jeho jsoucnost.“72

71 ŽÁK, František. Soustavná vérouka pro lid I, IV - O Bohu v jednom v Trojici, Praha:

V. Kotrba, 1915, s. 402.

72 Tamtéž. 
Tato IV. kniha ve skutečnosti sestává ze dvou traktátů, tedy nejprve De Deo uno a následně De Deo trino. Mezi oběma traktáty není hlubší vazba. My se sice zaměříme pochopitelně na pojednání o Trojici, leč pohlédneme i do prvně zmíněného.

Pasáž o jediném Bohu vykazuje dobově standardní parametry i obsah. Je vcelku jasné, že v pojednání o Trojici se projeví některé prvky z De Deo uno, nicméně opačným směrem vazba neexistuje naprosto žádná. To je patrné např́iklad z toho, že v kapitole o jménech Božích si Žák vůbec neklade otázku, jaký je poměr mezi hlavním Božím jménem Jahve a osobou Boha Otce. Podnětné je snad konstatování: „Ostatních jmen (Božích) užívá Písmo také o pohanských bozích, jména Jahve toliko o Bohu pravém.“73

Jestliže $\mathbf{v}$ př́padě velkého souboru kázání, který jsme analyzovali výše, jsme mohli vnímat jakousi tendenci k překonání dvou oddělených pojednání, protože F. Žák předřadil téma Trojice rozboru vlastností Boží přirozenosti, nyní nic takového konstatovat není možno.

Pojednání o Trojici se nachází na stranách 501-566. Nejprve se vyjasňují základní pojmy: bytnost, podstata, přirozenost, hypostaze, osoba: „osoba je hypostase rozumná“. ${ }^{74}$ Je tedy evidentní, že Žák aplikuje přednsotně Boethiovu definici. Není zde ani zmínka o „já“.

Mezi základní pojmy patří i bludy: Modalismus je nyní definován správně jako tři způsoby projevování se jediného Boha v dějinách. Zmíněni jsou monarchiáni, mezi subordinacianisty je uváděn pouze Arius. Dále se hovoří o triteismu („třibožci“). Jako bludaři jsou jmenováni: Fothios, unitáři, Swenborg (†1722), ovšem bez hlubšího vysvětlení. ${ }^{75}$

Další kapitolka pojednává o Trojici v Písmu svatém. Opakuje se $\mathrm{v}$ podstatě totéž jako $\mathrm{v}$ předchozím spisu, je však doplněna klasická scéna návštěvy tří poslů u Abraháma (srov. Gn 18). ${ }^{76}$ Opět ani zmínka o problému poměru mezi Jahve a osobou Otce. Žák tedy nedokázal vystihnout jeden ze stěžejních problémů trinitologie.

V prezentaci novozákonních základů trinitologie se opět vychází z Mt 28,19. Důležitou roli ale hrají i další místa, kupříkladu verš Lk 1,35, který je čten trinitárně: „Moc Nejvyššího“ odkazuje na Otce a „Duch svatý“ na třetí božskou osobu. Vtělení je tedy popisováno

\footnotetext{
73 Srov. tamtéž, s. 425.

74 Tamtéž, s. 503.

75 Srov. tamtéž, s. 503-505.

76 Srov. tamtéž, s. 506-509.
} 
jako dílo celé Trojice. ${ }^{77}$ Ačkoliv je dnes možná také jiná lektura, totiž v tom smyslu, že „Moc Nejvyššího“ a „Duch svatý“ jsou v zásadě dvě označení téhož ve smyslu biblického paralelismu, rozhodně to neznamená, že Žákovo vnímání daného textu by bylo možno jednoznačně označit jako něco mylného nebo nepřijatelného. ${ }^{78}$ Náš autor rovněž upozorňuje na 1 Jan 5,7, kriticky však podotýká, že se zřejmě jedná o pozdější vsuvku (Comma Joanneum) ${ }^{79}$ Řeč je pochopitelně také o trinitární epifanii při Ježíšově křtu v Jordánu a o dalších typických místech.

Není zde ale ani sebemenší zmínka o velikonočním tajemství jako vrcholném zjevení Trojice. Manualistika prostě kříž zařadila do pojednání o překonání hříchu a vzkříšení zase do apologetiky nebo fundamentální teologie, takže $\mathrm{v}$ pojednání o Trojici se s vrcholem zjevení nesetkáme. Jaký div, že trinitologie pak vypadá pouze jako řešení rébusu $1=3$ ? Pak následuje pasáž o pravém Synově božství, za níž je zařazeno zkoumání, zda v Novém zákoně je Duch svatý označen jako Bůh. Opět se setkáváme s již zmíněným argumentem ze Sk 5,3-4.80 Nezajímavé není následující konstatování: „V Písmě není Duch svatý nikdy počítán mezi tvory. “81 Zmíněný argument má při prokazování toho, že Nový zákon obsahuje pravdu o božství Ducha svatého navzdory tomu, že zde nenajdeme jednoznačný výrok typu: „Duch svatý je Bůh," určitě svoji váhu.

Třetí kapitolka pojednává o církevním podání. Jedná se o čtyřstránkový náznak dějin dogmatu. Velmi zajímavé je vstřícné hodnocení „měkkého“ subordinacioanismu přednicejských církevních otců:

77 Srov. tamtéž, s. 509.

78 Srov. VALENTINI, Alberto. Maria secondo le Scritture. Figlia di Sion e Madre del Signore, Bologna: EDB, 2007, s. 104. Zmíněný autor o dané záležitosti informuje, zároveň ale obhajuje trojiční interpretaci textu v tom smyslu, že Duch svatý zde představuje osobu, a to na základě chronologicky starší pavlovské koncepce pneumatu. Srov. také PAVEL VI. Marialis cultus, čl. 25 - český překlad in: MPMA, Matka Páné. Památka Prítomnost - Naděje, Kostelní Vydří: Karm. nakl., 2003, s. 143-144 - papež zde hovoří o potřebě trinitárního rozměru mariánské úcty, který pochopitelně souvisí také s Lk 1,35, i když zde toto místo není citováno.

79 Srov. ŽÁK, František. Soustavná vérouka pro lid I, s. 511. Náš autor tedy respektuje prohlášení Sv. officia (Kongregace pro nauku víry) ze dne 13. 8. 1897, nicméně v určitém smyslu již předjímá další výrok téhož grémia z roku 1927, v němž se konstatuje, že předchozí dispozice měla pouze disciplinární charakter, a proto nebrání katolickým teologům hovořit o tom, že daná pasáž je pozdější vsuvka do inspirovaného novozákonního textu. Srov. DSH, č. 3682.

81 Srov. tamtéž, s. 515. 
V době před sněmem nicejským, kdy vědecká bohověda teprve začínala, nebylo ještě přesných výrazů a rčení; i není tedy divu, že mnozí nevědí, jak mají věc vyjádřiti, nebo že se vyjadřují nejasně, slovy, která dnes zdají se nám chybná, ale pochopena jsouce v duchu spisovatelově, dávají správný smysl. ${ }^{82}$

Opět je položen mimořádný důraz na otázku Filioque. Žák se netají s důvody proč:

Pro Čechy má řečený rozkol zvláštní důležitost, poněvadž Rusové a četní Slované náležejí k němu. Proto se ještě zvlášt poohlédneme, jak o vycházení Ducha svatého učili Otcové západu a hlavně východu. ${ }^{83}$

Opravdu velmi zajímavé jsou údaje, podle nichž se na Východě nauka o vycházení Ducha svatého i ze Syna objevovala už v pátém století (např. synoda v Seleukii 410). Škoda že nejsou uvedeny prameny, z nichž autor čerpal. První, kdo výlovně učil, že Duch vychází výhradně z Otce, měli být monotheleti v první polovině sedmého století. Náznaky nauky o vycházení Ducha svatého i ze Syna by měly být v dílech Origena a Athanasia. ${ }^{84}$ Žák na rozdíl od svého spisu, jejž jsme analyzovali výše, nyní zmiňuje východní verzi, podle níž Duch svatý vychází z Otce skrze Syna, a hodnotí ji jako podvojné řešení srovnatelné s klasickou západní naukou o vycházení Ducha z Otce i Syna. ${ }^{85}$

V kapitole, která pojednává o Trojici a lidském rozumu se setkáváme s přehledem moderních trinitárních bludů. Mastrofini chtěl podle našeho autora řečené tajemství vysvětlovat matematicky na základě úvah o nekonečnu. Günther zase zaváděl do trinitologie hegelovské principy. Rosmini podle Žáka upadl do panteismu. Přinejmenším hodnocení prvního a třetího zmíněného autora by dnes určitě neobstálo. Zajímavá je rozhodně zmínka tehdy ještě žijícího T. G. Masaryka:

Masaryk (kalvínec) míní, že katolík musí věřiti: $1=3$, jsou tři bozi, ale tito tři bozi jsou jeden Bůh. Proti takovým nehorázným potupám jsme bezmocní. ${ }^{86}$

\footnotetext{
82 Srov. tamtéž, s. 518.

83 Srov. tamtéž, s. 526.

84 Srov. tamtéž, s. 528-529.

85 Srov. tamtéž, s. 529.

86 Tamtéž, s. 539.
} 
Masaryk je uveden jako př́klad protestantských myslitelů, kteří odmítali učení o Trojici. Problém je v tom, že profesor Masaryk sice ve svém výkladu českých dějin sympatizoval s českými nekatolickými myšlenkovými proudy, v nichž viděl přítomnost humanismu, jeho př́mé instituční sepětí s evangelickou církví je však záležitostí přinejmenším diskutabilní. ${ }^{87}$ Uvedená výtka proti dobové trinitologii nepochází od Masaryka samotného, používali ji totiž četní myslitelé devatenáctého století. Jistěže není zcela spravedlivá, protože jednota se týká přirozenosti, zatímco trojičnost osob, ve hře jsou tudíž dva zřetele, a proto žádný katolický ni pravoslavný teolog netvrdí, že jedna rovná se tři. Uvědomme si, že Žákovo dílo vyšlo v roce 1915, tedy v době první světové války, a profesor Masaryk byl císařsko-královským státním aparátem považován za nepřítele monarchie, takže tato více méně negativně laděná zmínka jeho osoby v katolickém teologickém díle může mít i určité dobové politické pozadí. Zároveň se ale naskýtá otázka, zda uvedená kritika ze strany humanistického filosofa by neměla vést katolické teology k zamyšlení nad tím, jakým způsobem tajemství Trojice v tehdejší době prezentovali, nebot oni sami vše soustředili na řešení rébusu $1=3$, aniž by dokázali vysvětlit praktický význam ústř̌edního tajemství víry a zejména to, jak by se mělo promítat nejen do života, ale také do zbytku dogmatické teologie.

Zmiňován je také Richard od Svatého Viktora, který vyvozoval Trojici z toho, že Bůh je dobrý a že je láska, což implikuje sdílení. Žák bohužel nedokázal pochopit genialitu tohoto autora a jeho prínos hodnotí přezíravě. 88

Další kapitola pojednává o psychologické teorii. ${ }^{89}$ Je výslovně zmíněn Augustin, není ale ani jednou skutečně citován. Psychologická teorie, o jejímž kritickém hodnocení v dnešní době jsme se již zmínili výše, je opět základním kamenem spekulativního přístupu k tajemství Trojice.

Velký posun oproti předchozímu analyzovanému spisu shledáváme v prezentaci teorie vnitrobožských vztahů. Žák již ví, že vztahy jsou celkově čtyři. Zmíněné hypostatické relace jsou reálně identické s Boží podstatou či přirozeností. ${ }^{90}$ Otcovství je reálně identické s osobou Otce,

87 Pokud se jedná o Masarykova stanoviska vzhledem k náboženství srov. NEUDORFLOVÁ, Marie L. T. G. Masaryk - obránce náboženství, kritik klerikalismu. In NEŠPOR, Zdeněk R. - KAISEROVÁ, Kristina (ed.). Varieta české religiozity v „dlouhém“ 19. stoleti (1780-1918), Ústí n. L.: V a H. Print Hlávko, s. 279-288.

88 Srov. ŽÁK, František. Soustavná vérouka pro lid I, s. 540.

89 Srov. tamtéž, s. 540-548.

90 Srov. tamtéž, s. 549. 
synovství s osobou Syna a vycházení (tedy pasivní darování) s osobou Ducha svatého. Dokonce se setkáváme s odmítnutím ideje absolutní, tedy nevztahové osoby Boha Otce. ${ }^{91}$ To vše je znatelný posun, nicméně Žák nedokáže překročit stín své doby a klade větší důraz na psychologickou teorii. Nedostatkem je také to, že neshledáváme ani náznak použití teorie sociální, která je zřetelně nejvhodnější příležitostí k přemostění mezi trinitární teorií a praxí, spiritualitou. Za tento defekt západní trinitologie je ale zodpovědný Augustin, který ve svém De Trinitate danou teorii úplně skartoval.

Pasáž věnovaná přivlastňování je správně uvedena konstatováním, že přívlastky (appropriationes) se přisuzují jednotlivé osobě přednostně, leč nikoli výlučně. Žák ovšem nezná základní model přivlastňování přes příčiny, který je výslovně představen v již připomenuté encyklice Lva XIII., Divinum illud munus z roku 1897.

František Žák hovoří dokonce i o perichorezi, kterýžto termín však tlumočí zcela nevhodně jako „vbydleni“, což by odpovídalo spíše výrazu inhabitatio, jímž se obvykle označuje přebývání osob Trojice v srdci člověka, a nikoli vzájemnému prostupování osob Trojice. Základem perichoreze je podle Žáka především sama jediná Boží podstata. Náš autor ale opět nedokáže z tohoto tajemství vytěžit zhola nic pro spiritualitu a život. ${ }^{92}$ Celé snažení českého teologa končí kapitolou o posláních, která však nepřináší nic, co by překračovalo rámec publikací z dané doby.

\section{Hodnocení}

Jestliže jsme konstatovali, že v tomto případě bude položen poněkud větší důraz na seznámení s životními osudy našeho autora, pak je třeba to zohlednit také v závěrečném hodnocení. Položme si nyní otázku, jaké důvody vedly k tomu, že osobnost našeho autora v zásadě upadla do zapomenutí? Podle mého soudu to byly především obrovské nesnáze svízelných dob německé okupace a poté komunismu. Zmíněná epocha nelidské krutosti rozhodně nepřála jak hlubšímu a spravedlivějšímu pohledu do minulosti, tak projevování vděku těm, kdo v předchozích dobách vykonali tak mnoho na vinici Páně. Snad si mohu dovolit konstatovat, že nikomu, kdo se nyní byt́ jen letmo seznámil s životními osudy Františka Žáka, nemůže být tato postava

91 Srov. tamtéž, s. 552.

92 Srov. tamtéž, s. 557nn. 
nesympatická. Určitě by se tedy slušelo, aby bylo důstojně připomenuto sto padesáté výročí od narození tohoto apoštolského muže. Přinejmenším proto, že se výrazně zasloužil o prohloubení našich vztahů k pravoslavnému Rusku, že se v klíčových letech dějin podílel na vytváření česko-slovenské vzájemnosti, že se bezvýhradně nasazoval v apoštolském a křestanském osvětovém díle. Velikost člověka přece neodvisí výlučně od vrcholové vědeckosti jeho myšlenkového výkonu.

Nyní pár slov k myšlenkovému výkonu Františka Žáka v oblasti, která je specifickým předmětem našeho zájmu. Určitě není nesnadné konstatovat, že mezi prvním a druhým analyzovaným spisem existují nepopiratelné kvalitativní posuny, nicméně František Žák nikde nepřekračuje rámec své doby. Inklinace k pojetí Boha jako supesubjektu je silně patrná stejně jako izolace trinitologie od zbytku teologie a od života. Vše vyznívá jako řešení rébusu $1=3$. Nikde se nedozvíme, k čemu všechna ta námaha vlastně je. Jen marně bychom hledali zmínku velikonočního tajemství. Žákova trinitologie prostě a jednoduše pojednává o imanentní Trojici, ale rozhodně se při tom nevychází z Trojice ekonomické. Náznak pneumatologie sice shledáváme v souboru kázání, která jsme analyzovali, nicméně v Soustavné katolické vérouce jsme nic takového nenalezli. Otázkou je, zda si pisatel Soustavné katolické vérouky byl ještě vědom toho, k čemu vybízel ve svých kázáních o vlastnostech Božích. Bylo by však nespravedlivé omezit se při hodnocení Žákovy trojiční teologie pouze na konstatování negativ. Některé prvky výkonu našeho autora si uchovávají určitou hodnotu i dnes. Jedná se naprríklad o spravedlivější postoj k přednicejským církevním otcům, kteří nejsou výslovně označováni jako subordinacianisté. Zmínka o tom, že v Novém zákoně se o Duchu svatém nikdy nemluví jako o tvoru, rovněž není zcela nezajímavá. Jako určité zpestření mohou působit dnes již nezvyklé české výrazy: doxologie = slávoslov; jsoucna v možnosti = možniny. Není sporu o tom, že je třeba projevovat úctu k nesmírné námaze, již František Žák tak horlivě vynaložil $\mathrm{v}$ díle popularizace a osvěty, zároveň si však musíme upř́mně přiznat, že jeho trojiční teologie v Soustavné katolické vérouce pro lid aplikovanou metodologií a myšlenkovou úrovní nevyvolává v dnešním čtenáři žádné velké nadšení. Problém spočítá rovněž v tom, že i pro vzdělané laiky byl daný spis poměrně náročný a především tak ř́kajíc „k neučtení“, na druhé straně ani v době svého vzniku nemohla objemná Soustavná katolická vérouka splňovat kritéria kladená na vysokoškolskou učebnici. 


\section{ABSTRACT \\ CTIRAD VÁCLAV POSPÍŠIL \\ Life of František Žák SJ (1862-1934) and his Trinitarian Theology}

The aim of this study is the critical analysis of the Trinitarian Theology and Pneumatology of František Žák SJ (1862-1934) who is the author of the many theological books and articles, romances, stories, stage plays, spiritual songs... In the introduction the author explains the reasons of this study and presents the basic hermeneutical points of view of his analysis. Then he introduces the work and the life of František Žák and finds two texts of this author which deal with the Trinitarian Theology and Pneumatology. The life of Žák is more interesting than his theological work which suffers from the same deficiencies which were typical for Dogmatic Theology of his era, but in Žák's work there are some elements which are actual up to these days.

\section{Key words}

trinitarian theology, pneumatology, theology, dogmatic theology, history of the Czech dogmatic theology 